\title{
Disruption of androgen signaling during puberty affects Notch pathway in rat seminiferous epithelium
}

Alicja Kamińska† ${ }^{\dagger}$ Sylwia Marek, Laura Pardyak, Małgorzata Brzoskwinia, Piotr Pawlicki, Barbara Bilińska and Anna Hejmej*

\begin{abstract}
Background: Onset of spermatogenesis at puberty is critically dependent on the activity of hypothalamic-pituitarygonadal axis and testosterone production by Leydig cells. The aim of this study was to examine whether activation of Notch receptors and expression of Notch ligands and effector genes in rat seminiferous epithelium are controlled by androgen signaling during puberty.

Methods: Peripubertal (5-week-old) Wistar rats received injections of flutamide (50 mg/kg bw) daily for 7 days to reduce androgen receptor (AR) signaling or a single injection of ethanedimethane sulphonate (EDS; $75 \mathrm{mg} / \mathrm{kg}$ bw) to reduce testosterone production. Gene and protein expressions were analyzed by real-time RT-PCR and western blotting, respectively, protein distribution by immunohistochemistry, and steroid hormone concentrations by enzymelinked immunosorbent assay. Statistical analyses were performed using one-way ANOVA followed by Tukey's post hoc test or by Kruskal-Wallis test, followed by Dunn's test.

Results: In both experimental models changes of a similar nature in the expression of Notch pathway components were found. Androgen deprivation caused the reduction of MRNA and protein expression of DLL4 ligand, activated forms of Notch1 and Notch2 receptors and HES1 and HEY1 effector genes $(p<0.05, p<0.01, p<0.001)$. In contrast, DLL1, JAG1 and HES5 expressions increased in seminiferous epithelium of both flutamide and EDS-treated rats $(p<$ $0.05, p<0.01, p<0.001)$.

Conclusions: Androgens and androgen receptor signaling may be considered as factors regulating Notch pathway activity and the expression of Hes and Hey genes in rat seminiferous epithelium during pubertal development. Further studies should focus on functional significance of androgen-Notch signaling cross-talk in the initiation and maintenance of spermatogenesis.
\end{abstract}

Keywords: Notch signaling, Androgens, Testis, Puberty

\footnotetext{
* Correspondence: anna.hejmej@uj.edu.pl

${ }^{\dagger}$ Alicja Kamińska and Sylwia Marek contributed equally to this work.

Department of Endocrinology, Faculty of Biology, Institute of Zoology \& Biomedical Research, Jagiellonian University, Gronostajowa 9, 30-387 Krakow, Poland
}

(c) The Author(s). 2020 Open Access This article is licensed under a Creative Commons Attribution 4.0 International License, which permits use, sharing, adaptation, distribution and reproduction in any medium or format, as long as you give appropriate credit to the original author(s) and the source, provide a link to the Creative Commons licence, and indicate if changes were made. The images or other third party material in this article are included in the article's Creative Commons licence, unless indicated otherwise in a credit line to the material. If material is not included in the article's Creative Commons licence and your intended use is not permitted by statutory regulation or exceeds the permitted use, you will need to obtain permission directly from the copyright holder. To view a copy of this licence, visit http://creativecommons.org/licenses/by/4.0/ The Creative Commons Public Domain Dedication waiver (http://creativecommons.org/publicdomain/zero/1.0/) applies to the data made available in this article, unless otherwise stated in a credit line to the data. 


\section{Background}

Spermatogenesis is a process in which germ cells undergo precisely timed sequence of phases of proliferation and differentiation to produce male gametes, spermatozoa. Onset of spermatozoa production at puberty is critically dependent on the activity of hypothalamic-pituitarygonadal axis and testosterone production by Leydig cells [1]. Testosterone acts to regulate spermatogenesis predominantly through androgen receptor (AR), a member of nuclear receptor subfamily 3 . The majority of evidence indicates that differentiating germ cells do not express the AR and Sertoli cells are considered as major mediators of androgen action in the control of spermatogenesis [2]. In rat Sertoli cells the AR is detected from postnatal day (PD) 5. The number of AR expressing Sertoli cells and condensation of AR nuclear staining gradually increase with age and stage-dependent expression pattern appears between PD 21 and 35, preceding an increase of circulating testosterone from PD 35 [3-5]. Studies on Sertoli cellspecific AR knockouts or gain-of-function transgenic mouse models clearly demonstrated the connection between androgen-induced Sertoli cell maturation and germ cell progression through meiosis [6, 7]. At puberty onset androgens drive Sertoli cell maturation, repressing antymüllerian hormone $(\mathrm{AMH})$ expression and controlling the formation of blood-testis barrier. As a consequence, a supportive environment for the completion of germ cell meiosis is created and the full progression of spermatogenesis occurs. Maintenance and dynamics of the blood-testis barrier, as well as Sertoli cell-spermatid adhesion and sperm release from seminiferous epithelium (spermiation) are also dependent on androgen action in Sertoli cells [1].

Although numerous studies have been performed to elucidate the role of androgens in initiation and maintenance of spermatogenesis, the molecular pathways that link androgen signaling to the control of germ cell development are still not completely understood. Herein, we hypothesize that Notch signaling pathway may be regulated by androgen action in seminiferous epithelium at puberty. Notch pathway is an evolutionarily conserved juxtacrine signaling network which plays a role in coordinating cell differentiation and cell-fate decisions in many organs. Activation of this pathway is induced by binding of the extracellular domain of Notch receptors with membranous ligands present on neighboring cells. This results in the cleavage of the Notch extracellular domain by disintegrin and metalloproteinases (ADAMs), while intracellular domain is cleaved by the $\gamma$-secretase complex. Released Notch intracellular domain (NICD) translocates to the nucleus, where it builds up coactivator complex composed of recombination signal binding protein RBP-J, Mastermind-like 1 (MAML1) and NICD, together with histone acetylases [for review see [8]. The
Notch coactivator complex facilitates histone acetylation leading to the expression of target genes. Several Notch effector genes belonging to hairy/enhancer of split (Hes) and Hes-related with YRPW motif (Hey) families are expressed in the testis [9]. HES and HEY proteins are known as transcriptional repressors that act directly on target promoters to regulate cellular processes [10].

In the control of spermatogenesis special attention was put to Notch1 receptor signaling in Sertoli and germ cells. Importance of Notch1 signaling was evidenced by studies on gain-of-function models. Conditional activation of the Notch1 intracellular domain (N1ICD) in germ cells caused increase of germ cell apoptosis, reduction in sperm counts and a progressive loss of testis weight with age. On the other hand, constitutive activation of Notch1 signaling in Sertoli cells led to premature differentiation of gonocytes, followed by gonocyte apoptosis, which resulted in infertility [11]. Although Notch1 knockout in either Sertoli or germ cells had no effect on spermatogenesis, likely due to redundancy of Notch receptors, pharmacological inhibition of Notch pathway caused spermatogenesis defects [11-13].

During postnatal development of rodent testis changes in the pattern of Notch pathway components expression were observed; specifically Notch1 receptor replaces Notch3 in Sertoli cells of peripubertal mouse [9, 14, 15]. The role and regulation of Notch 2 was demonstrated to date in fetal mouse testis [16] and in tumor Leydig cells [17], but only scarce data exist on its localization in seminiferous epithelium $[18,19]$.

It was previously reported that circulating levels of testosterone directly affected Notch signaling in progenitor Leydig cells, regulating the maintenance of fetal Leydig cell population [20], but the potential function of androgens in the control of Notch pathway activity in seminiferous epithelium has not been explored yet. Given that androgens play a prominent role in the initiation of sperm production around puberty, the involvement of Notch pathway in the androgen responses of testicular cells is intriguing. Therefore, in the present study we focused on the Notch receptors activation and expression of Notch ligands and effector genes in rat seminiferous epithelium following manipulations of androgen signaling or production during puberty. Since some components of Notch pathway, as well as the AR are also present in the Leydig cells, these cells were included into analyses where needed.

\section{Methods}

\section{Animals and treatments}

Pubertal (5-week-old) Wistar rats (Rattus norvegicus) were obtained from the animal facility at Faculty of Pharmacy, Jagiellonian University, Krakow. The rats were maintained on a 12-h light and 12-h dark cycle and were allowed food and water ad libitum. Rats ( $n=6 /$ each group) received sc. 
injections of flutamide ( $50 \mathrm{mg} / \mathrm{kg}$ bw) daily for 7 days as described previously [21] or single injection of ethanedimethane sulphonate (EDS; $75 \mathrm{mg} / \mathrm{kg} \mathrm{bw}$ ) as described previously [22, 23]. Flutamide reduces androgen action by inhibiting AR transcriptional activity, whereas EDS selectively destroys Leydig cells, the main source of androgens, leading to significant decrease in testosterone production $[24,25]$. Vehicle-treated as well as saline-treated controls were performed ( $n=6$ each group). Since there were no differences neither in testosterone levels nor in the expression of studied genes (data not shown) between vehicletreated as well as saline-treated groups, only the latter was presented in the Results section as a control group.

Animals were sacrificed by inhalation of $4-5 \%(\mathrm{v} / \mathrm{v})$ isoflurane at day 8 after first flutamide or EDS injection. Testes were dissected immediately and were either frozen (one testis from each animal, $n=6 /$ each group) in liquid nitrogen for real-time RT-PCR and western blot analyses or fixed either in Bouin's fluid (Sigma-Aldrich; $n=3$ /each group) or $4 \%$ paraformaldehyde (Santa Cruz Biotechnology; $n=3$ /each group). Paraffin tissue sections were used for eosin-hematoxylin staining and immunohistochemistry. Blood was collected and testosterone concentrations were measured in blood plasma using DRG Testosterone ELISA (DRG International) according to the manufacturer's instructions. All animal procedures followed the guidelines of the Polish Animal Welfare act and were approved by the 2nd Local Institutional Animal Care and Use Committee in Krakow, Poland (189/2018 and 85/2019).

\section{RNA isolation, reverse transcription and real-time quantitative RT-PCR}

Total RNA was extracted from the testes $(n=6 /$ each group) with $\mathrm{TRIzol}^{\circ}$ reagent (Life Technologies) according to the manufacturer's instructions. Contaminating DNA products were removed with TURBO DNA-free ${ }^{\text {Tw }}$ Kit (Ambion) according to the manufacturer's instructions. The quality and yield of the RNA were evaluated by measuring the A260:A280 ratio (NanoDrop ND2000 Spectrophotometer, Thermo Scientific) and by electrophoresis. A260:280 ratios not lower than 1.9 were accepted for cDNA synthesis.

cDNA was synthetized using purified RNA and the High-Capacity cDNA Reverse Transcription Kit (Applied Biosystems) according to the manufacturer's instructions. Parallel reactions for each RNA sample were run in the absence of reverse transcriptase to evaluate genomic DNA contamination.

StepOne Real-time PCR system (Applied Biosystems) was used for real-time RT-PCR analyses with the cDNA templates as described above and primers listed in Table 1 (Institute of Biochemistry and Biophysics, Polish Academy of Science). Amplification efficiency was determined as described by Svec et al. [26]. All PCR assays displayed efficiency between 95 and 102\%.

Detection of amplification products of tested genes and the reference genes (B2m, Rn18s and $A c t b)$ was performed with $10 \mathrm{ng}$ cDNA, $0.5 \mu \mathrm{M}$ primers, and SYBR Green master mix (Applied Biosystems) according to the manufacturer's instructions. To confirm amplification specificity, the PCR products were subjected to melting curve analysis and subsequent agarose gel electrophoresis. In all real-time RT-PCR reactions, a negative control corresponding to RT reaction without the reverse transcriptase enzyme and a blank sample were carried out (data not shown). mRNA expressions were normalized to the mean expression of the reference genes $R n 18 s, B 2 m$ and Actb mRNA (relative quantification,

Table 1 Primers used in real-time RT-PCR analyses

\begin{tabular}{|c|c|c|c|c|}
\hline Genes & Forward sequence & Reverse sequence & Product size $(b p)$ & Annealing temp. $\left({ }^{\circ} \mathrm{C}\right)$ \\
\hline$\overline{A c t b}$ & AAGTACCCCATTGAACACGG & ATCACAATGCCAGTGGTACG & 257 & 52 \\
\hline$B 2 m$ & GGACTGGTCTTTCTATATCCTGGC & GATCACATGTCTCGATCCCAGTAG & 150 & 58 \\
\hline Cldn11 & TGTCAACAGCAGCAAGATGGCG & GCTCCAAGGGCCTGTGGGC & 332 & 57 \\
\hline DIl1 & TCAGATAACCCTGACGGAGGC & AGGTAAGAGTTGCCGAGGTCC & 185 & 56 \\
\hline DI/4 & GCTGGAAGTGGATTGTGG & CTTGTCGCTGTGAGGATAC & 405 & 51 \\
\hline Hes1 & GGCAGGCGCACCCCGCCTTG & GCAGCCAGGCTGGAGAGGCT & 170 & 62 \\
\hline Hes5 & ACCGCATCAACAGCAGCATT & AGGCTTTGCTGTGCTTCAGGT & 135 & 55 \\
\hline Hey 1 & AAAGACGGAGAGGCATCATCG & GCAGTGTGCAGCATITCAGG & 126 & 55 \\
\hline Jag1 & AACTGGTACCGGTGCGAA & TGATGCAAGATCTCCCTGAAAC & 216 & 54 \\
\hline Notch1 & GCAGCCACAGAACTTACAAATCCAG & TAAATGCCTCTGGAATGTGGGTGAT & 445 & 56 \\
\hline Notch2 & GCTGTCCTCTTCATGCTGCA & AGCAGAAGTCAAGACAGTC & 405 & 51 \\
\hline $\mathrm{PCl}$ & TGACCCCCAAAAGGACCAC & TGGTCCAGGTAGTAGGAATACCCA & 237 & 54 \\
\hline Rhox5 & TCATCATTGATCCTATTCAGGGTATG & СTCTCCAGCCTGGAAGAAAGC & 380 & 55 \\
\hline Rn18s & CATTCGAACGTCTGCCCTAT & GTTTCTCAGGCTCCCTCTCC & 128 & 56 \\
\hline
\end{tabular}


$R Q=1)$ with the use of the $2^{-\Delta \Delta C t}$ method, as previously described [27].

\section{Western blot analysis}

The proteins were extracted from testicular tissue $(n=$ 6/each group) with a cold RIPA buffer (Thermo Scientific) supplemented with protease inhibitors (Sigma-Aldrich). Separation of protein preparations by SDS-PAGE under reducing conditions and transfer of proteins to polyvinylidene difluoride membranes were performed as described before [28]. Nonspecific binding sites were blocked with a solution of $5 \%(\mathrm{wt} / \mathrm{v})$ non-fat dry milk containing 0.1\% (v/v) Tween 20 . Next the membranes were incubated with the respective primary antibody (Table 2) at $4{ }^{\circ} \mathrm{C}$ overnight, followed by a horseradish peroxidase-conjugated secondary antibody (1:3000; Vector Laboratories) for $1 \mathrm{~h}$ at room temperature. Proteins were detected by chemiluminescence [29], and documented with a ChemiDocTM XRS+ System (Bio-Rad Laboratories). All immunoblots were stripped and reprobed with an anti- $\beta$-actin antibody as the loading control [30]. The molecular weights of target proteins were estimated by reference to standard proteins (Sigma-Aldrich). To obtain quantitative results, immunoblots were analyzed densitometrically using the ImageLab software (Bio-Rad Laboratories). Each data point was normalized against its corresponding actin data point.

\section{Immunohistochemistry}

Immunohistochemistry was performed on $5 \mu \mathrm{m}$ sections of testicular tissue. Antigen retrieval, endogenous peroxidase neutralization and blocking of non-specific binding sites were performed as described previously [31]. Thereafter, the sections were incubated overnight at $4{ }^{\circ} \mathrm{C}$ with a primary antibody (Table 2). On the next day, a biotinylated goat anti-rabbit or horse anti-goat secondary antibody (1:400; Vector Laboratories) was applied for $60 \mathrm{~min}$.
The staining was developed with an avidin-biotinylated horseradish peroxidase complex solution (1:100; VECTASTAIN Elite ABC Reagent, Vector Laboratories) for $30 \mathrm{~min}$, followed by $0.05 \% 3.3^{\prime}$-diaminobenzidine tetrachloride containing $0.01 \%(\mathrm{v} / \mathrm{v}) \mathrm{H}_{2} \mathrm{O}_{2}$ and $0.07 \%$ (wt/v) imidazole. Sections were counterstained with Mayer's hematoxylin. All slides within an experiment were processed identically at the same time so that the staining intensity among different sections of the testis could be compared. To validate specificity of primary antibodies used for immunohistochemistry, western blotting was performed (for detail see subsection "Western blot analysis"). Negative controls in the absence of primary antibodies were performed for each immunostaining. Sections were examined with a Nikon Eclipse $\mathrm{Ni}$ microscope (Nikon Instech Co., Ltd., Tokyo, Japan).

For semi-quantitative analysis of immunohistochemical reaction testicular sections were recorded using Nikon Eclipse Ni microscope (Nikon Instech Co., Ltd., Tokyo, Japan) equipped with $\times 100$ objective lens (NA 1.4) and high-definition DS-Fi2 video camera (Nikon Instech Co., Ltd.). Approximately 40 images from testicular sections of each examined animal ( $n=3$ /each group) were analyzed. The outlines of the cells were marked manually and the gray level (GL) of marked areas was measured. Protein levels in Sertoli and germ cells were measured throughout all stages of seminiferous epithelium with the public domain Image software (National Institutes of Health, Bethesda, MD). The intensity of the reaction was expressed as relative optical density (ROD) of diaminobenzidine brown reaction products and was calculated with the following formula:

$$
\begin{aligned}
\mathrm{ROD} & =\mathrm{OD}_{\text {spicemen }} / \mathrm{OD}_{\text {background }} \\
& =\log \left(\mathrm{GL}_{\text {blank }} / \mathrm{GL}_{\text {specimen }}\right) / \log \left(\mathrm{GL}_{\text {blank }} / \mathrm{GL}_{\text {specimen }}\right)
\end{aligned}
$$

where $\mathrm{OD}$ is optical density, $\mathrm{GL}_{\text {specimen }}$ - the gray level for the stained area, $\mathrm{GL}_{\text {background }}$ - gray level of

\begin{tabular}{|c|c|c|c|c|}
\hline Antibody & Host species & Vendor & Cat. Number & Dilution \\
\hline Anti-actin & Mouse & Sigma-Aldrich & A2228 & $1: 3000(\mathrm{WB})^{\mathrm{a}}$ \\
\hline Anti-DLL1 & Rabbit & Sigma-Aldrich & SAB2100593 & 1:1000 (WB), 1:100 (IHC) \\
\hline Anti-DLL4 & Rabbit & Abcam & AB7280 & 1:2000 (WB), 1:400 (IHC) \\
\hline Anti-HES1 & Rabbit & Thermo Fischer Scientific & PA5-28802 & 1:1000 (WB); 1:100 (IHC) \\
\hline Anti-HES5 & Goat & Santa Cruz Biotechnology & sc- 13,859 & 1:300 (WB), 1:50 (IHC) \\
\hline Anti-HEY1 & Rabbit & Thermo Fischer Scientific & PA5-40553 & 1:500 (WB), 1:100 (IHC) \\
\hline Anti-JAG1 & Rabbit & Thermo Fischer Scientific & PA5-72843 & 1:3000(WB), 1:600 (IHC) \\
\hline Anti-LHR & Rabbit & Santa Cruz Biotechnology & sc- 25,828 & 1:1000 (WB), 1:200 (IHC) \\
\hline Anti-N1ICD & Rabbit & Abcam & Ab8925 & 1:1000 (WB), 1:200 (IHC) \\
\hline Anti-N2ICD & Rabbit & Sigma-Aldrich & SAB4502020 & 1:500 (WB), 1:200 (IHC) \\
\hline
\end{tabular}

Table 2 Details of primary antibodies used for western blot and immunohistochemistry

${ }^{a} W B$ western blot, $I H C$ immunohistochemistry 
unstained area (background) and $\mathrm{GL}_{\text {blank }}$ - the gray level measured after the slide was removed from the light path [32]. Data were expressed as means $\pm S D$.

\section{Morphometry}

Hematoxyline and eosine (H-E) staining was performed on $5 \mu \mathrm{m}$ sections of Bouin-fixed paraffin-embedded testicular tissue. The diameter of the seminiferous tubules was measured at $\times 100$ magnification using ImageJ software. On average 60 circular tubules were measured per slide. When the tubular sections were slightly oval, only the smaller diameter was measured. Mean was determined for each animal from control and treatment groups. Data were expressed in $\mu \mathrm{m}$ as means $\pm S D$.

The area of the interstitium occupied by Leydig cells was calculated from Image measurements of freehand outlines drawn along the circumference of LHR-positive cell clusters. The area of Leydig cells was determined at $\times 400$ magnification in 40 random fields of vision for each section examined, and was expressed as a percentage of the area obtained from control group calculations $\pm S D$. For the control group, area was adopted as $100 \%$.

Numbers of abnormal, retained or degenerating spermatids were counted on $\mathrm{H}-\mathrm{E}$ sections and expressed as a percentage of total number (100\%) of elongated spermatids counted. For each animal, elongated spermatids from 200 seminiferous tubules cross-sections were counted. Data were expressed as means $\pm S D$.

\section{Statistical analysis}

Statistical differences were assessed using one-way ANOVA followed by Tukey's post hoc comparison test when the data showed a normal distribution and homogeneity of variances. Otherwise, a nonparametric Kruskal-Wallis test, followed by Dunn's test were used when the data did not show a normal distribution and/or homogeneity of variances. Statistical analyses were performed on raw data using Statistica 10 software (StatSoft Inc.). Data from real-time RT-PCR and densitometry analyses were expressed in arbitrary units (AU) as means \pm SD. Data from testosterone assay were expressed in $\mathrm{ng} / \mathrm{mL}$ as means $\pm S D$. Data were considered statistically significant at $" p<0.05, * * p<0.01$, $* * * * 0.001$.

\section{Results}

Efficacy of androgen deprivation by flutamide or EDS was examined through analysis of luteinizing hormone receptor (LHR; marker of Leydig cells), plasma testosterone concentrations, and the expression of three genes regulated by androgens in Sertoli cells, Rhox5, PCI and Cldn11 [33]. Blockade of the AR by flutamide inhibits classical testosterone signaling in testicular cells as well as the negative feedback of testosterone on the pituitary gland. This leads to an increase in circulating luteinizing hormone, resulting in stimulation of Leydig cell [34]. As expected, in the present study flutamide treatment led to Leydig cell hypertrophy and significant increase in testosterone secretion $(p<0.01)$ (Fig. 1A-C). EDS, an alkylating agent, which specifically eliminates Leydig cells, caused a 70\% reduction of area occupied by Leydig cells within 1 week $(p<0.01)$ (Fig. 1A). This was correlated with marked reduction of LHR level in testicular homogenates $(p<0.001)$ (Fig. 1B). Plasma testosterone concentrations were also much lower than in control males $(p<0.01)$ (Fig. 1C). In agreement, we found that the expression of Rhox5, PCI and Cldn11, was significantly downregulated in the testes of both flutamide and EDStreated males $(p<0.01, p<0.001)$ (Fig. 1D). There was about $10 \%$ reduction of seminiferous tubules diameter in the experimental groups $v s$. control group $(p<0.01)$ (Fig. $1 \mathrm{E}$ ), and abnormal or degenerating elongated spermatids were observed in seminiferous epithelium (Fig. 1F, G). However, all germ cell populations (spermatogonia, spermatocytes, round and elongated spermatids) were present in all groups of rats. Thus, short-term androgen signaling disruption models used herein allowed for efficient androgen signaling reduction without producing profound alterations in germ cell composition in seminiferous epithelium of peripubertal males.

Effects of androgen deprivation on the expression of JAG1, DLL1 and DLL4 ligands were differential. We have found that mRNA and protein expression of DLL1 and JAG1 was upregulated $(p<0.05, p<0.01)$ (Fig. $2 \mathrm{~A}$ $\left.\mathrm{B}^{\prime}\right)$. In contrary, DLL4 was reduced in the testes of both experimental models $(p<0.01, p<0.001)$ (Fig. 2C, C').

Three Notch pathway ligands JAG1, DLL1 and DLL4 were detected in seminiferous epithelium of pubertal rats (Fig. 3A - C, E - G, I - K), whereas in Leydig cells only DLL4 was found (Fig. 3I'- K'). JAG1 was localized predominantly in elongating spermatids, weak staining was also found in spermatogonia and Sertoli cells. An increase of JAG1 protein expression was not evident in immunohistochemical analysis (Fig. 3A - D). DLL1 was expressed in Sertoli cells, spermatogonia, and elongated spermatids. Immunohistochemistry followed by densitometry revealed highest DLL1 increase in Sertoli cells $(p<0.01)$ (Fig. 3E $\mathrm{H})$. DLL4 was the most ubiquitous ligand in seminiferous epithelium, being localized in Sertoli cells and germ cell throughout seminiferous epithelium $(p<0.05, p<0.01$, $p<0.001$ ) (Fig. 3I). The most severe decrease of DLL4 signal was found in basal compartment of seminiferous epithelium of flutamide-treated rats (Fig. 3J). Notably, DLL4 signal was increased in elongated spermatids present in EDS-treated males $(p<0.05)$ (Fig. 3K, L).

The expression of Notch1 receptor mRNA as well as the level of its active form N1ICD were significantly reduced in flutamide and EDS treated groups $(p<0.01, p<0.001)$ (Fig. 4A, A'). In both experimental groups reduced N2ICD 


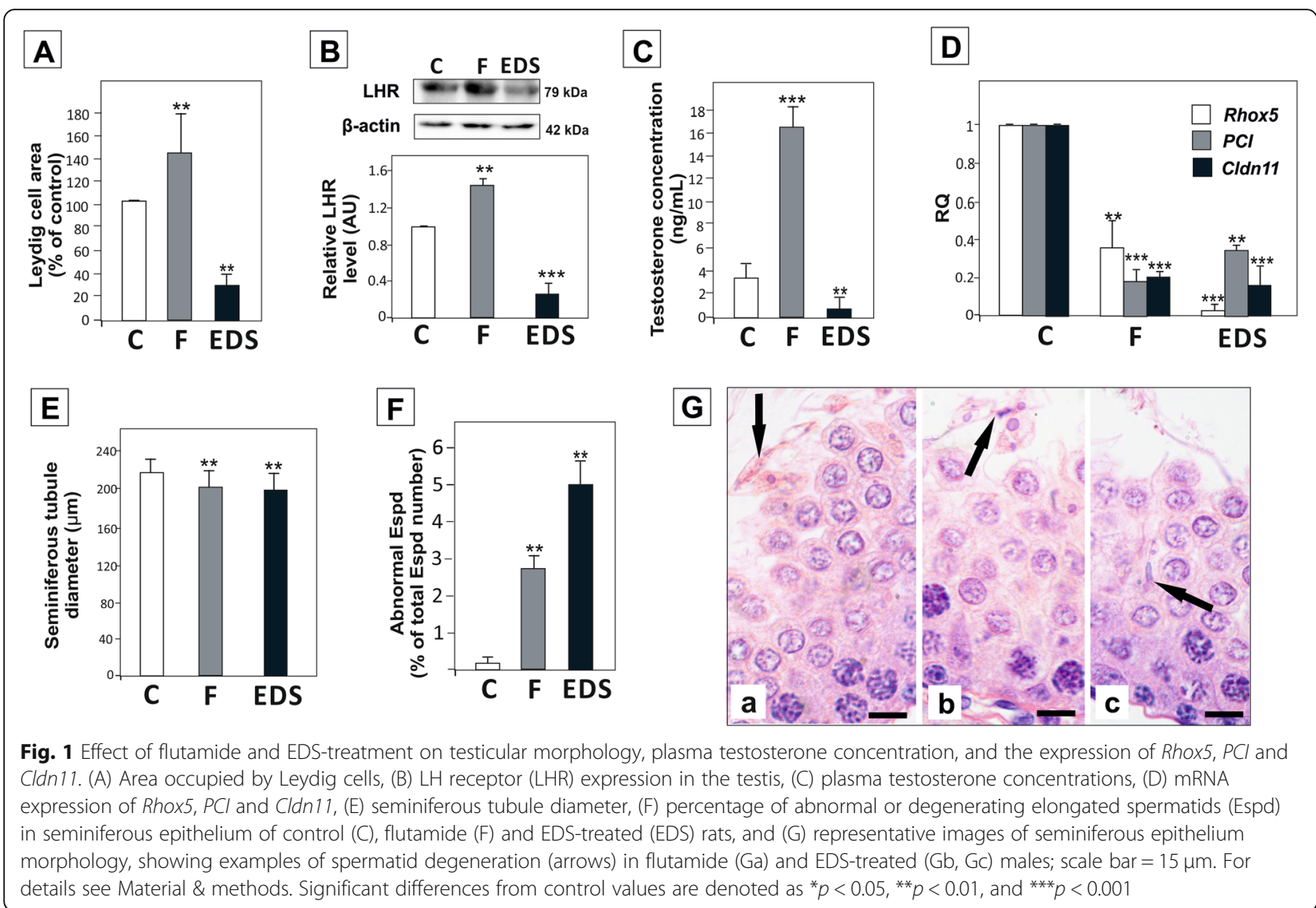

level was also detected, in spite of up-regulated Notch2 mRNA expression $(p<0.01, p<0.001)$ (Fig. 4B, $\left.\mathrm{B}^{\prime}\right)$.

As demonstrated by immunohistochemistry, activated form of Notch1 receptor, N1ICD, was expressed in basal compartment of seminiferous epithelium in Sertoli cells and spermatogonia, then appeared in late pachytene spermatocytes and continued to be present in germ cells up to elongated spermatids (Fig. 5A, A'). N1ICD showed nuclear localization in the cells of seminiferous epithelium (Fig. 5A, A'), whereas in Leydig cells both nuclear and cytoplasmic signal was detected (Fig. 5A"). Apparent decrease of N1ICD immunoexpression was found in both seminiferous epithelium and Leydig cells of flutamide and EDS-treated rats $(p<0.05, p<0.01)$ (Fig. 5B, $\left.B^{\prime}, B^{\prime \prime}, C, C^{\prime}, C^{\prime \prime}, D\right)$.

The highest immunoexpression of full-length Notch2 was observed in adluminal compartment of seminiferous epithelium and in the interstitial tissue (Additional Fig. 1), whereas the localization of N2ICD was restricted to early steps of germ cell differentiation, from spermatogonia up to early pachytene spermatocytes (Fig. 5E - G'). The most prominent decrease of N2IDC was observed in spermatogonia, preleptotene and leptotene/zygotene spermatocytes of EDS-treated males $(p<$ 0.01) (Fig. 5H).
Attenuation of testosterone signaling had differential effects on the expression of the effector genes. Significant reduction of Heyl and Hes 1 mRNA and protein levels was found following androgen withdrawal $(p<$ 0.01, $p<0.001$ ) (Fig. 6A - B'). In contrast, Hes5 mRNA and protein expressions were upregulated $(p<0.05, p<$ 0.001) (Fig. 6C, C').

HEY1 was restricted to Sertoli cells and Leydig cells, where it produced very weak cytoplasmic signal (Fig. 7A, $\left.A^{\prime}\right)$. In both flutamide and EDS-treated rats HEY1 signal almost completely disappeared; significant reduction of immunostaining intensity was confirmed with densitometry $(p<0.01)$ (Fig. 7B - D). In seminiferous epithelium HES1 exhibited exclusively nuclear localization and was detected in Sertoli cells, spermatogonia, and elongated spermatids (Fig. 7E). Nuclear and cytoplasmic staining was found in Leydig cells (Fig. 7E'). The reduction of HES1 immunoexpression was detected in elongated spermatids in both experimental groups, and in Sertoli cells of EDS-treated males (Fig. 7F, F', G, G', H). In rats exposed to flutamide a slight increase of immunostaining was found in Sertoli cells $(p<0.001)$ (Fig. 7F, H). HES5 was detected in Sertoli cells, spermatogonia, elongated spermatids and Leydig cells; the most noticeable increase of HES5 immunoreactivity was found in basal 


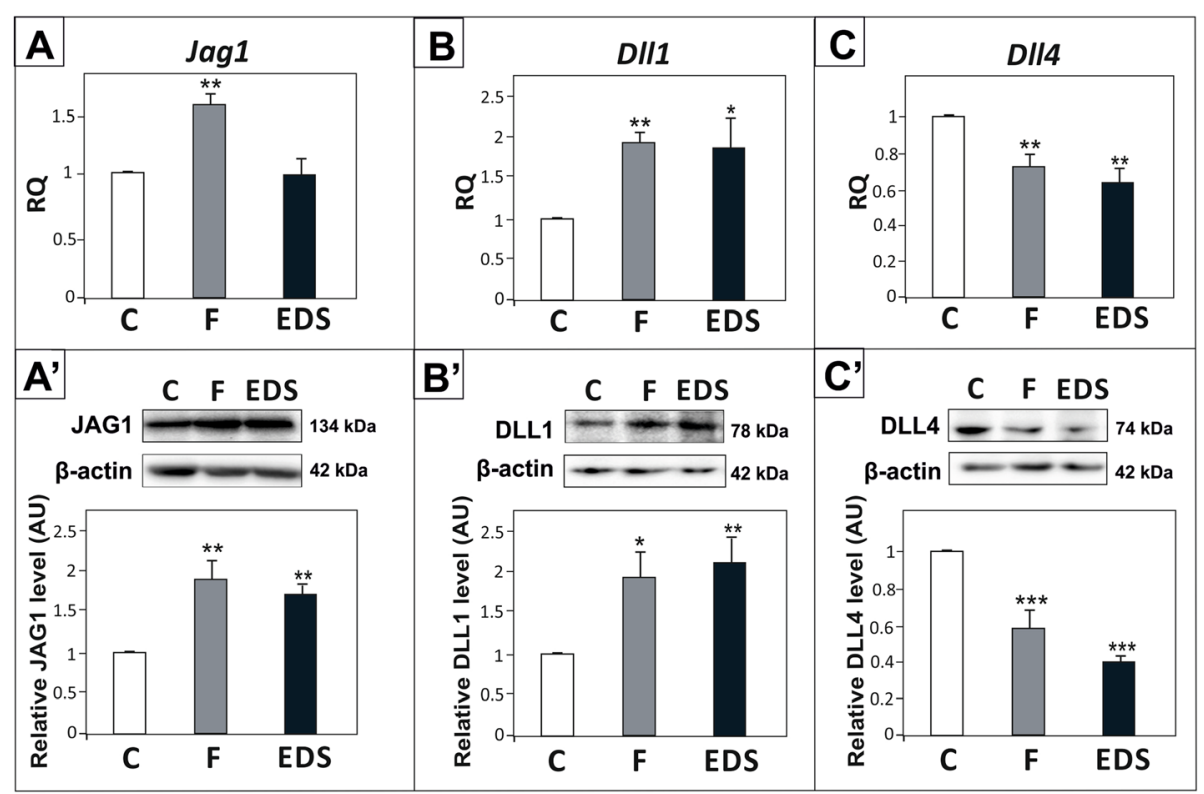

Fig. 2 Effect of flutamide (F) and EDS on Jag1, D/l1 and D/l4 expression in rat testis. (A - C) Relative expression of Jag1, D/l1 and D/l4 mRNAs was determined using real-time RT-PCR analysis. The histograms are the quantitative representation of data of three independent analyses ( $n=6$ each group). The expression values of the individual genes were normalized to the mean expression of the reference genes (Rn18s, B2m and Actb) as an internal control. Relative quantification $(\mathrm{RQ})$ is expressed as mean \pm SD. Significant differences from control values are denoted as $*^{*} p<0.01$ and ${ }^{* *} p<0.001$. ( $A^{\prime}-C^{\prime}$ ) Relative protein expression of JAG1, DLL1 and DLL4 was determined using western blot. The histograms are the quantitative representation after densitometry of data (mean \pm SD) of three independent analyses ( $n=6$ each group). The relative level of studied protein was normalized against its corresponding actin data point. The protein levels within the control group were arbitrarily set at 1 . Significant differences from control values are denoted as ${ }^{*} p<0.05,{ }^{* *} p<0.01$, and ${ }^{* * *} p<0.001$

compartment of seminiferous epithelium of flutamidetreated rats $(p<0.01)$ (Fig. 7I - L).

\section{Discussion}

In the present study we found that androgen signaling in peripubertal males controls the expression of Notch pathway ligands and activity of Notch signaling in the testis. To reveal this interaction, we reduced androgen signaling in rats by either blocking the AR or testosterone production. It should be noted that elimination of Leydig cells with EDS not only reduces the level of testosterone, but also affects production of other Leydig cell-derived factors. However, in both models used in our study similar changes in the expression of Notch pathway components in seminiferous epithelium were found, which indicates that disruption of androgen action is the main reason of observed alterations. Furthermore, the changes were usually more evident when the AR was blocked. This observation suggests that classical pathway of androgen action via $A R$ is an important mechanism responsible for the regulation of Notch signaling in pubertal testis by androgens. Interaction between AR signaling and Notch pathway was earlier found in human endometrial cell lines MFE-296 and AN3CA; overexpression of the AR resulted in increased expression of Notch1 and Hes1, which was attenuated by co-transfection with AR siRNA [35].

Analysis of the expression of Notch ligands following androgen signaling disruption revealed differential responses of particular ligands. It is likely that in the testis, similarly as in other tissues, the balance between Notch ligands is important for undisturbed functioning [36]. Of note, different ligands expressed in one tissue often have opposing activities [37, 38]. Therefore, the maintenance of balanced expression and action of the ligands may result from their diverse (antagonistic) regulation by a common factor, as it was demonstrated in breast cancer cells [39].

DLL4 decreased significantly following androgen signaling withdrawal, which correlated with decreased level of the active form of Notch1 receptor in Sertoli cells. Based on IHC results, DLL4 decrease in basal compartment of seminiferous epithelium seems to be strongly dependent on AR blockade. Since the AR is detected only in somatic testicular cells, changes in ligand expression in germ cells may result from indirect effects mediated likely via Sertoli cells. In case of EDS-induced testosterone withdrawal, decrease of Dll4 mRNA and protein level might be ascribed predominantly to the loss of Leydig cells, however reduced immunoexpression in seminiferous epithelium was also observed. 


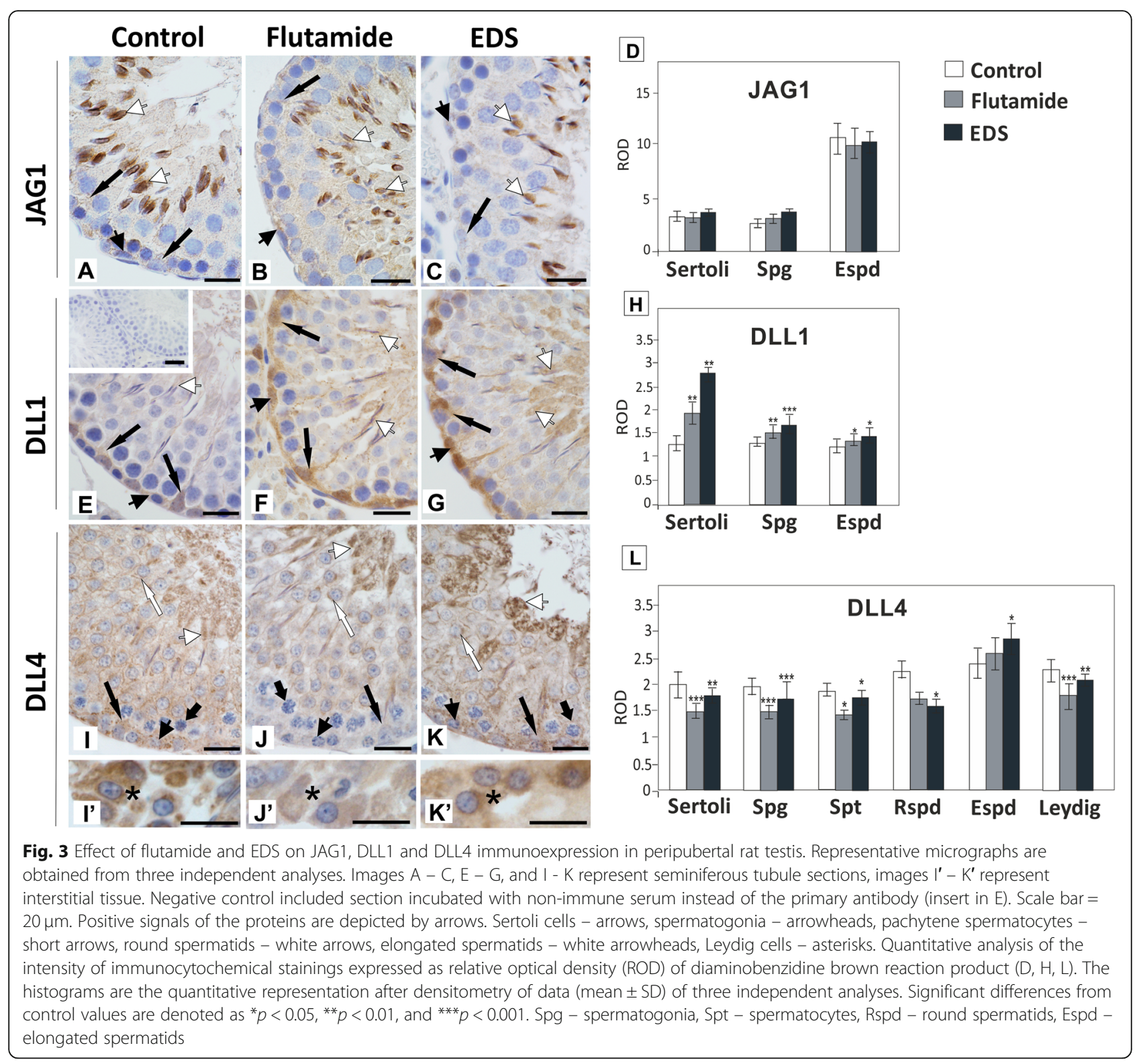

In contrast to DLL4, DLL1 and JAG1 appeared to be negatively regulated by androgens since both flutamide and EDS exposure resulted in up-regulation of their expressions. It should be mentioned that increased expression of Notch ligands may exert either stimulatory or inhibitory effect on Notch pathway activation. In case of the expression of both ligand and receptor within the same cell, response called cis-inhibition is observed [40]. In this study DLL1 expression was enhanced predominantly in Sertoli cells in which the activation of Notch1 receptor significantly decreased, which suggest the possibility of above-mention effect.

The expression of JAG1 was found mainly in elongating spermatids of pubertal rats. In our study both spermatogonia and Sertoli cells exhibited only scarce signal, indicating low level of this protein. Such localization was in contrast to those observed previously in adult rat, where the highest expression of this ligand was detected in spermatogonia $[41,42]$. In adult mouse, however the localization of JAG1, performed with the same technique as used in the present study was in agreement with our findings [9]. Although both qRT-PCR and western blot analyses revealed increased JAG1 expression after flutamide, IHC followed by densitometry did not demonstrate significant changes of signal intensity. The limitation of this study lies in semi-quantitative nature of densitometry analysis of immunohistochemical staining. The relationship between the concentration of a DAB reaction product and its absorbance is not linear and DAB-based immunohistochemistry has limited dynamic range [43]. As such, 


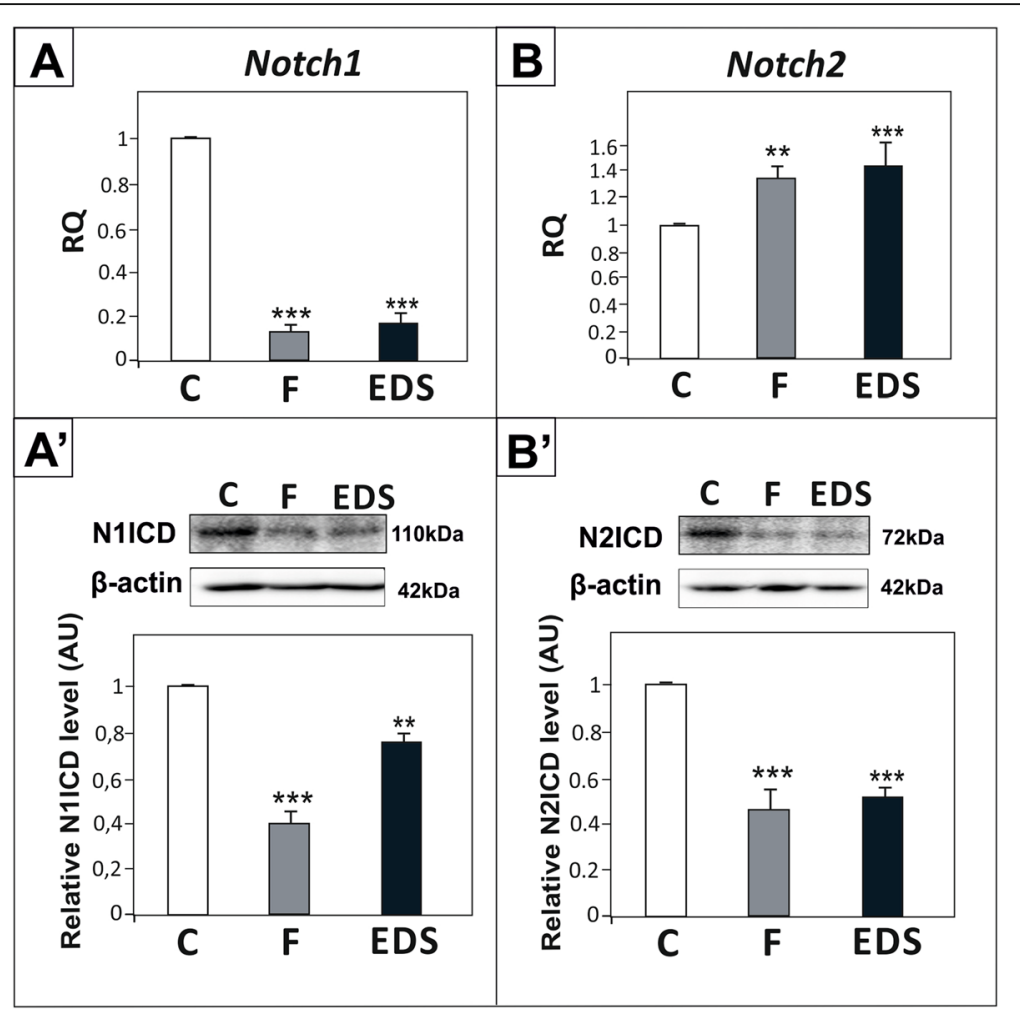

Fig. 4 Effect of flutamide (F) and EDS on Notch1 and Notch2 expression in peripubertal rat testis. (A, B) Relative expression of Notch1 and Notch2 mRNAs was determined using real-time RT-PCR analysis. The histograms are the quantitative representation of data of three independent analyses ( $n=6$ each group). The expression values of the individual genes were normalized to the mean expression of the reference genes ( $R n 18 s, B 2 m$ and $A c t b)$ as an internal control. Relative quantification (RQ) is expressed as mean \pm SD. Significant differences from control values are denoted as ${ }^{* *} p<0.01$ and ${ }^{* * *} p<0.001$. (A', B') Relative protein levels of N1ICD and N2ICD were determined using western blot. The histograms are the quantitative representation after densitometry of data (mean \pm SD) of three independent analyses ( $n=6$ each group). The relative level of studied protein was normalized against its corresponding actin data point. The protein levels within the control group were arbitrarily set as 1. Significant differences from control values are denoted as ${ }^{*} p<0.05$, ${ }^{* *} p<0.01$, and ${ }^{* * *} p<0.001$

this approach has limited resolution in measuring modest differences and some minor changes in protein expressions between experimental groups might be undetectable with this method.

Since JAG1 was localized mostly to elongating spermatids, where it produced strong signal, it is likely that further increase of the signal was not detectable using densitometric approach. On the other hand, attempts to reduce signal intensity in spermatids resulted in concomitant complete loss of the signal in Sertoli cells and spermatogonia. Thus, it is likely that overall increase of JAG1 protein expression came from elongated spermatids. Nevertheless, further studies are needed in order to clearly identify cells in which JAG1 expression is androgen regulated.

Altogether, the expression of Notch ligands was deregulated after depletion of testosterone signaling. It is likely that these changes led directly to decreased activation of Notch1 and Notch2 receptors. However, the reduction in N1ICD level maybe a consequence of downregulation of Notch1 mRNA expression as well, because we found attenuation of both Notch1 mRNA and cleaved Notch1 protein expression.

Decreased expression of N1ICD in seminiferous epithelium was accompanied by the reduction of HEY1 expression in Sertoli cells after EDS. Slight increase of HES1 found in Sertoli cells of flutamide-treated rats may suggest that regulation of Hes1 expression in these cells is controlled via AR-independent androgen signaling. Such non-classical androgen pathways have been recently revealed [44], but their possible role in the control of Hes 1 requires further research.

To date the significance of Notch1/HES1/HEY1 pathway in the testis was precisely determined only in Sertoli cells. It was established that HES1 and HEY1 inhibit the production of glial cell line-derived neurotrophic factor (GDNF) and expression of retinoid acid metabolizing enzyme CYP26B1 by Sertoli cells [42, 45]. The results by Murta et al. [13] suggested also a regulatory role of Notch signaling in spermatid elongation and maintenance of the elongated spermatid anchoring system. Notably, according to earlier findings 


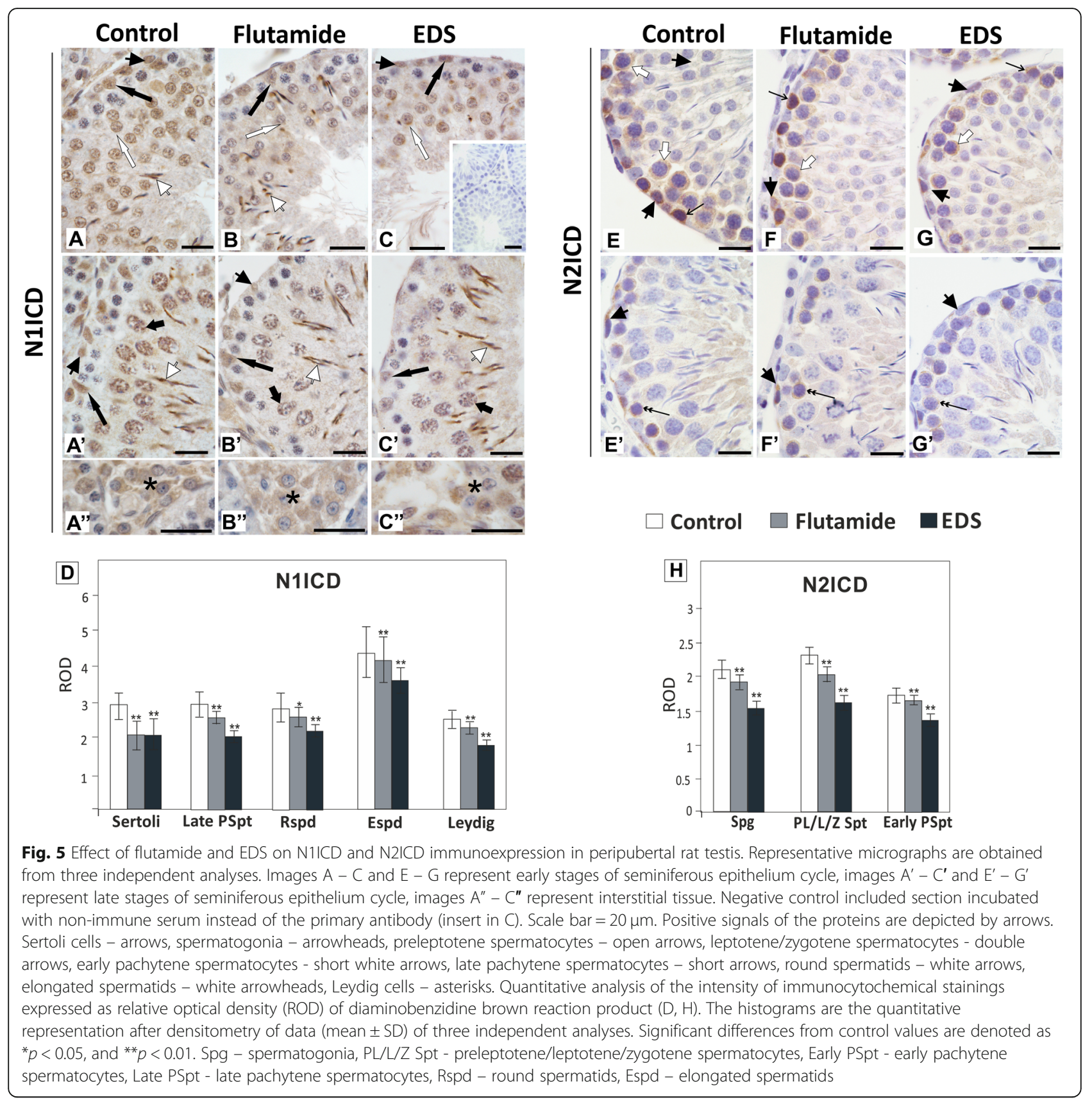

elongating spermatids development is androgendependent $[46,47]$.

It is worth mentioning that in mouse HES1 was detected in spermatogonia of immature testis. In adult mice the expression in spermatogonia decreased and HES1 was detected mainly in Sertoli cells $[9,15,48]$. In pubertal rats we found the expression of this protein in both spermatogonia and Sertoli cells. However, in contrary to the observations made in mice, in rat we detected clear HES1 signal also in elongated spermatids. This may suggest either species-dependent localization or expression specific for the first wave of spermatogenesis. Inhibition of androgen signaling or production led to reduced immunoexpression of HES1 in elongated spermatids. In the light of data presented herein, the interaction between androgen and Notch signaling may be important during spermiogenesis and is worth further in-depth investigation.

In agreement with the results of the present study an environmental endocrine disruptor possessing anti-androgenic activity, di-(2-ethylhexyl) phthalate, reduced Notch1 and HES1 expression in adult rat testis [49]. Our previous study demonstrated increased activation of Notch1/HEY1 pathway and decrease of HES5 following dibutyl phthalate exposure 


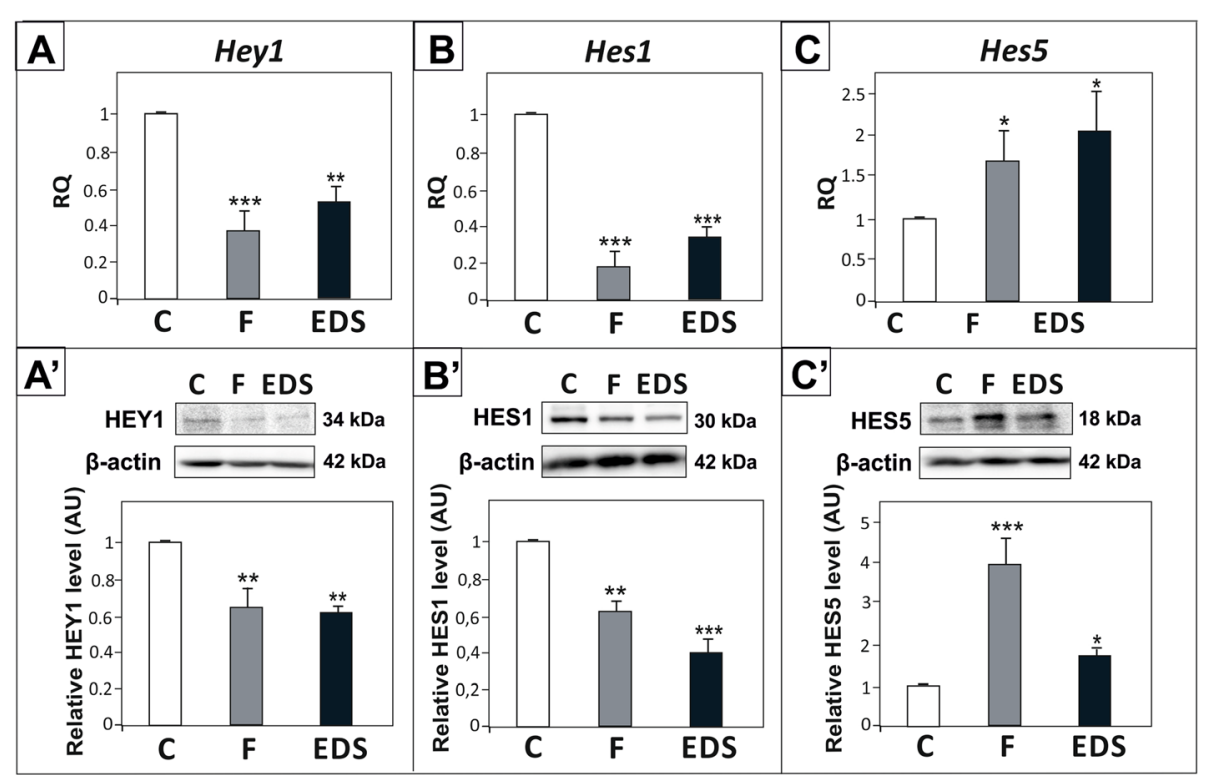

Fig. 6 Effect of flutamide (F) and EDS on Hey1, Hes1, and Hes5 expression in rat testis. (A - C) Relative expression of Hey1, Hes1, and Hes5 mRNAs was determined using real-time RT-PCR analysis. The histograms are the quantitative representation of data of three independent analyses, each in triplicate ( $n=6$ each group). The expression values of the individual genes were normalized to the mean expression of the reference genes (Rn18s, B2m and Actb) as an internal control. Relative quantification (RQ) is expressed as mean \pm SD. Significant differences from control values are denoted as ${ }^{* *} p<0.01$ and ${ }^{* * *} p<0.001$. ( $A^{\prime}-C^{\prime}$ ) Relative protein expression of HEY1, HES1 and HES5 was determined using western blot. The histograms are the quantitative representation after densitometry of data (mean \pm SD) of three independent analyses $(n=6$ each group). The relative level of studied protein was normalized against its corresponding actin data point. The protein levels within the control group were arbitrarily set at 1 . Significant differences from control values are denoted as ${ }^{*} p<0.05,{ }^{* *} p<0.01$, and ${ }^{* * *} p<0.001$

of adult rat testis in vitro [31]. The reason of this discrepancy is unclear; it cannot be however excluded that the latter effect was due to some other mechanisms of dibutyl phthalate action e.g. estrogenic or AhR-dependent [50-52].

To our knowledge there are no reports on N2ICD localization or function in rodent testes. Full-length Notch2 receptor appears in peripubertal mouse testis in germ cells entering meiosis and in adult rats is present in pachytene spermatocytes, spermatids and Leydig cells $[9,19]$. Similarly, our results demonstrated the highest immunoexpression of Notch2 in adluminal compartment of seminiferous epithelium and in the interstitial tissue of peripubertal rats. Surprisingly, this is in contrast to the localization of activated form of Notch2; we detected N2ICD predominantly in pre-meiotic germ cells and no signal was detected in Leydig cells. These observations suggest a possible role of Notch2-dependent signaling in early steps of germ cell differentiation. Androgen signaling deprivation resulted in decreased level of N2ICD in testes of experimental rats. However, the expression of Notch2 receptor mRNA was up-regulated. This may indicate that androgen signaling potentiates Notch2 receptor activation, but simultaneously is involved in the maintenance of proper level of Notch2 receptor expression in seminiferous epithelium of pubertal males.
N2ICD co-localized with Notch effector proteins only in spermatogonia, where HES1 and HES5 were detected. However, we did not observe significant effect of androgen signaling inhibition on HES1 immunoexpression in spermatogonia, whereas HES5 increased in these cells. Thus neither of the targets investigated herein seems to mediate Notch2 signaling in spermatogonia and the downstream pathway for Notch2 in seminiferous epithelium remains to be investigated. Nevertheless, the presence of N1ICD and N2ICD and Notch effector genes in spermatogonia strongly suggest that Notch pathway is involved in the control of these cells. In addition, Okada et al. [15] showed the expression of cleaved form of Notch3 receptor (N3ICD) and HES1 in prepubertal and adult mouse spermatogonia. Altogether, Notch signaling is clearly activated in spermatogonia via different Notch receptors, but whether each of them play specific role or they are functionally redundant remains to be explained.

Noteworthy, despite reduced activation of Notch receptors, the expression of HES5 was increased, most markedly in flutamide-treated males. This may suggest that in peripubertal testis androgens affect HES5 expression through AR-mediated, but Notchindependent mechanism. Such possibility was evidenced earlier in prostate cancer cells where another member of HES family, HES6, was regulated by 


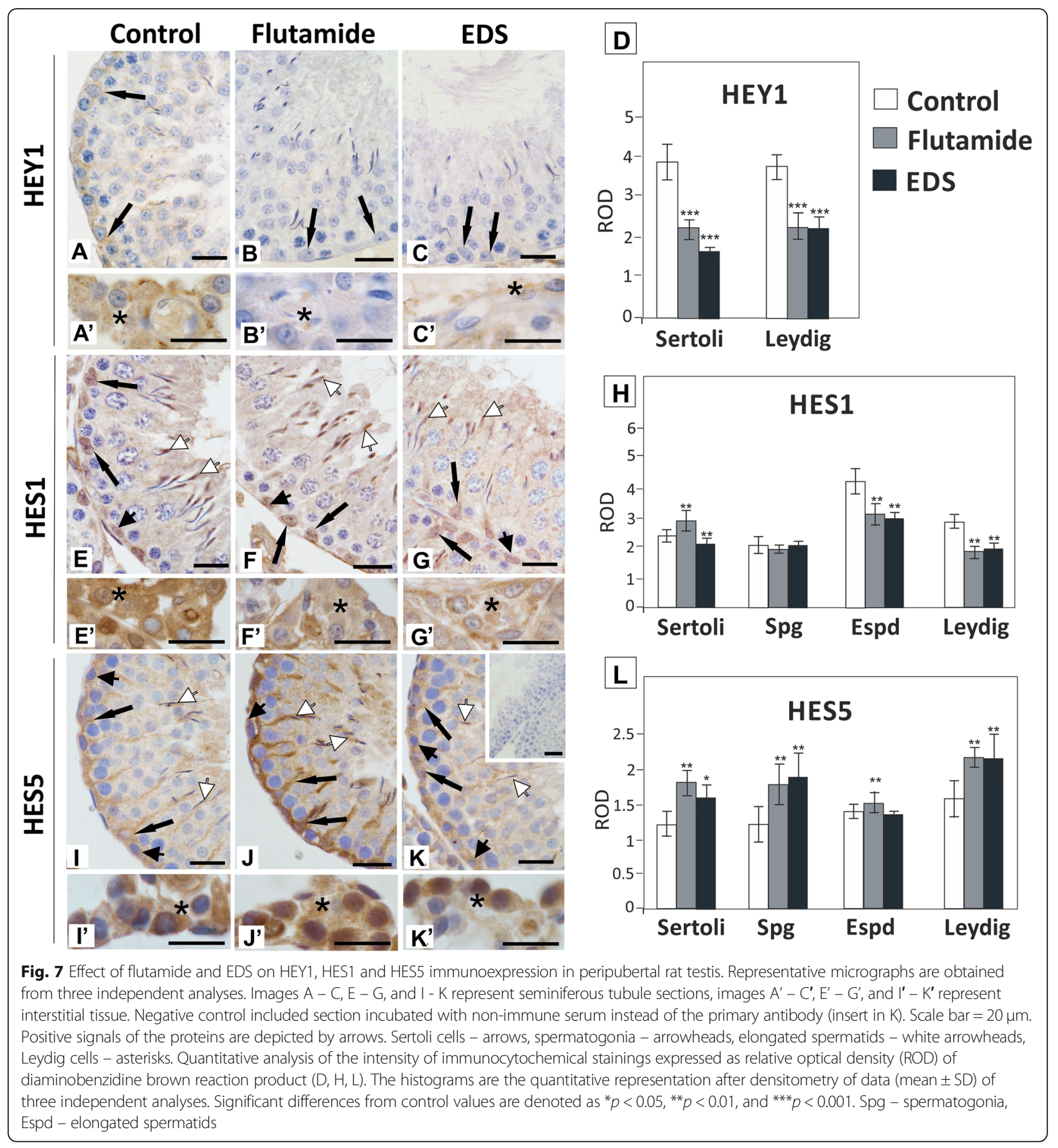

androgens without involvement of Notch signaling [53]. Recently the role of AR in control of Hes 5 expression was also found in spinal and bulbar muscular atrophy model [54].

Although this study has focused on seminiferous epithelium, we found that the expression of Notch pathway components was affected in Leydig cells following flutamide administration. In this model DLL4, N1ICD, HES1 and HEY1 were clearly reduced, which indicates that $\mathrm{AR}$ activity is required for maintenance of proper levels of these proteins in Leydig cells. Nevertheless, the role of Notch pathway in rat Leydig cell physiology during puberty is not defined and needs further investigation. The only protein negatively regulated by AR in Leydig cells was HES5. This effect, similarly as in seminiferous epithelium, may be explained by direct control of Hes 5 expression by AR signaling. 


\section{Conclusion}

Our results demonstrated for the first time that androgens and the AR may be considered as factors regulating Notch pathway activity and the expression of Hes and Hey genes in rat seminiferous epithelium during pubertal development. In our recent study we found that DLL1 and JAG1 ligands and Notch1 receptor activity are involved in the regulation of androgen receptors expression and action in Sertoli cells in vitro [55]. Altogether, these observations indicate the interrelationship between androgen and Notch pathways in seminiferous epithelium. Further studies should focus on functional significance of androgen-Notch signaling cross-talk in spermatogenesis.

\section{Supplementary information}

Supplementary information accompanies this paper at https://doi.org/10. 1186/s12958-020-00582-3.

Additional file 1. Immunoexpression of full-length Notch2 protein in rat testis. Scale bar $=20 \mu \mathrm{m}$. Cells showing highest signal intensity are depicted by arrows: late pachytene spermatocytes - short arrows, round spermatids - white arrows, elongated spermatids - white arrowheads, Leydig cells - asterisks.

\section{Abbreviations}

Actb: $\beta$-actin; ADAM: A disintegrin and metalloproteinase; AhR: Aryl hydrocarbon receptor; AR: Androgen receptor; B2m: $\beta$-2-microglobulin; CYP26B1: Cytochrome P450 26B1; D//1/DLL1: Delta-like 1; DII4/DLL4: Delta-like 4; EDS: Ethanedimethane sulphonate; GDNF: Glial cell line-derived neurotrophic factor; Hes 1/HES1: Hairy/enhancer of split 1; Hes5/HES5: Hairy/ enhancer of split 5; Hey1/HEY1: Hes-related with YRPW motif 1; Jag1/ JAG1: Jagged 1; LHR: Luteinizing hormone receptor; MAML1: Mastermind-like 1; N1ICD: Notch1 intracellular domain; N2ICD: Notch2 intracellular domain; NICD: Notch intracellular domain; PD: Postnatal day; RBP-J: Recombination signal binding protein; Rn18s: $18 \mathrm{~S}$ ribosomal RNA

\section{Authors' contributions}

$A K, S M, M B, L P, P P \& A H$ performed the research, AK, SM, BB \& AH analyzed the data, $\mathrm{AH}$ designed the research study and wrote the paper. The authors read and approved the final manuscript.

\section{Funding}

This work was supported by a grant 2017/25/B/NZ4/01037 (OPUS 13) from the National Science Centre (Poland).

\section{Availability of data and materials}

The datasets analyzed during the current study are available from the corresponding author on reasonable request.

\section{Ethics approval}

All animal procedures followed the guidelines of the Polish Animal Welfare act and were approved by the 2nd Local Institutional Animal Care and Use Committee in Krakow, Poland (189/2018 and 85/2019).

\section{Consent for publication}

Not applicable.

\section{Competing interests}

The authors declare that they have no competing interests.
Received: 22 October 2019 Accepted: 4 March 2020

Published online: 16 April 2020

\section{References}

1. O'Shaughnessy PJ. Hormonal control of germ cell development and spermatogenesis. Semin Cell Dev Biol. 2014;29:55-65.

2. O'Hara L, Smith LB. Androgen receptor roles in spermatogenesis and infertility. Best Pract Res Clin Endocrinol Metab. 2015;29:595-605.

3. Ketelslegers JM, Hetzel WD, Sherins RJ, Catt KJ. Developmental changes in testicular gonadotropin receptors: plasma gonadotropins and plasma testosterone in the rat. Endocrinology. 1978:103:212-22.

4. Bremner WJ, Millar MR, Sharpe RM, Saunders PT. Immunohistochemical localization of androgen receptors in the rat testis: evidence for stagedependent expression and regulation by androgens. Endocrinology. 1994; 135:1227-34.

5. You L, Sar M. Androgen receptor expression in the testes and epididymides of prenatal and postnatal Sprague-Dawley rats. Endocrine. 1998:9:253-61.

6. De Gendt K, Verhoeven G. Tissue- and cell-specific functions of the androgen receptor revealed through conditional knockout models in mice. Mol Cell Endocrinol. 2012:352:13-25.

7. Hazra R, Corcoran L, Robson M, McTavish KJ, Upton D, Handelsman DJ, Allan CM. Temporal role of Sertoli cell androgen receptor expression in spermatogenic development. Mol Endocrinol. 2013;27:12-24.

8. Bray SJ. Notch signalling in context. Nat Rev Mol Cell Biol. 2016;17:722-35.

9. Murta D, Batista M, Silva E, Trindade A, Henrique D, Duarte A, et al. Dynamics of Notch pathway expression during mouse testis post-natal development and along the spermatogenic cycle. PLoS One. 2013;8:e72767.

10. Weber D, Wiese C, Gessler M. Hey bHLH transcription factors. Curr Top Dev Biol. 2014;110:285-315

11. Garcia TX, Hofmann MC. NOTCH signaling in Sertoli cells regulates gonocyte fate. Cell Cycle. 2013;12:2538-45.

12. Huang Z, Rivas B, Agoulnik Al. NOTCH1 gain of function in germ cells causes failure of spermatogenesis in male mice. PLoS One. 2013;8:e71213.

13. Murta D, Batista M, Trindade A, Silva E, Henrique D, Duarte A, et al. In vivo notch signaling blockade induces abnormal spermatogenesis in the mouse. PLoS One. 2014;9:e113365.

14. Hayashi T, Yoshinaga A, Ohno R, Ishii N, Kamata S, Yamada T. Expression of the p63 and Notch signaling systems in rat testes during postnatal development: comparison with their expression levels in the epididymis and vas deferens. J Androl. 2004;25:692-8.

15. Okada R, Fujimagari M, Koya E, Hirose $Y$, Sato T, Nishina Y. Expression profile of NOTCH3 in mouse Spermatogonia. Cells Tissues Organs. 2017;204:283-92.

16. Liu C, Rodriguez K, Yao HH. Mapping lineage progression of somatic progenitor cells in the mouse fetal testis. Development. 2016;143:3700-10.

17. Kotula-Balak M, Milon A, Pawlicki P, Opydo-Chanek M, Pacwa A, Lesniak K, et al. Insights into the role of estrogen-related receptors $\alpha, \beta$ and $\gamma$ in tumor Leydig cells. Tissue Cell. 2018;52:78-91.

18. Dirami G, Ravindranath N, Achi MV, Dym M. Expression of Notch pathway components in spermatogonia and Sertoli cells of neonatal mice. J Androl. 2001:22:944-52.

19. Sahin Z, Bayram Z, Celik-Ozenci C, Akkoyunlu G, Seval Y, Erdogru T, et al. Effect of experimental varicocele on the expressions of Notch 1, 2, and 3 in rat testes: an immunohistochemical study. Fertil Steril. 2005;83:86-94.

20. Defalco T, Saraswathula A, Briot A, Iruela-Arispe ML, Capel B. Testosterone levels influence mouse fetal Leydig cell progenitors through notch signaling. Biol Reprod. 2013:88:91.

21. Zarzycka M, Chojnacka K, Mruk DD, Gorowska E, Hejmej A, Kotula-Balak M, et al. Flutamide alters the distribution of c-Src and affects the N-cadherin- $\beta$ catenin complex in the seminiferous epithelium of adult rat. Andrology. 2015:3:569-81.

22. Teerds KJ, De Rooij DG, Rommerts FF, Wensing CJ. The regulation of the proliferation and differentiation of rat Leydig cell precursor cells after EDS administration or daily HCG treatment. J Androl. 1988;9:343-51.

23. Guo J, Zhou H, Su Z, Chen B, Wang G, Wang CQ, et al. Comparison of cell types in the rat Leydig cell lineage after ethane dimethanesulfonate treatment. Reproduction. 2013;145:371-80.

24. Morris ID, Phillips DM, Bardin CW. Ethylene dimethanesulfonate destroys Leydig cells in the rat testis. Endocrinology. 1986;118:709-19.

25. Labrie F. Mechanism of action and pure antiandrogenic properties of flutamide. Cancer. 1993;72(Suppl 12):3816-27. 
26. Svec D, Tichopad A, Novosadova V, Pfaffl MW, Kubista M. How good is a PCR efficiency estimate: recommendations for precise and robust qPCR efficiency assessments. Biomol Detect Quantif. 2015;3:9-16.

27. Livak KJ, Schmittgen TD. Analysis of relative gene expression data using real-time quantitative PCR and the 2(-Delta Delta C(T)) method. Methods. 2001;25:402-8.

28. Chojnacka K, Zarzycka M, Hejmej A, Mruk DD, Gorowska E, Kotula-Balak M, et al. Hydroxyflutamide affects connexin 43 via the activation of PI3K/Aktdependent pathway but has no effect on the crosstalk between PI3K/Akt and ERK1/2 pathways at the Raf-1 kinase level in primary rat Sertoli cells. Toxicol in Vitro. 2016;31:146-57.

29. Mruk DD, Cheng CY. Enhanced chemiluminescence (ECL) for routine immunoblotting: an inexpensive alternative to commercially available kits. Spermatogenesis. 2011;1:121-2.

30. Górowska-Wójtowicz E, Hejmej A, Kamińska A, Pardyak L, Kotula-Balak M, Dulińska-Litewka J, et al. Anti-androgen 2-hydroxyflutamide modulates cadherin, catenin and androgen receptor phosphorylation in androgensensitive LNCaP and androgen-independent PC3 prostate cancer cell lines acting via PI3K/Akt and MAPK/ERK1/2 pathways. Toxicol in Vitro. 2017;40: 324-35.

31. Kamińska A, Pardyak L, Marek S, Górowska-Wójtowicz E, Kotula-Balak M, Bilińska B, et al. Bisphenol A and dibutyl phthalate affect the expression of juxtacrine signaling factors in rat testis. Chemosphere. 2018;199:182-90.

32. Smolen AJ. Image analytic techniques for quantification of immunocytochemical staining in the nervous system. In: Conn PM, editor. Methods in neurosciences. New York: Academic Press; 1990. p. 208-29.

33. Willems A, De Gendt K, Allemeersch J, Smith LB, Welsh M, Swinnen JV, et al. Early effects of Sertoli cell-selective androgen receptor ablation on testicular gene expression. Int J Androl. 2010;33:507-17.

34. Sarrabay A, Hilmi C, Tinwell H, Schorsch F, Pallardy M, Bars R, et al. Low dose evaluation of the antiandrogen flutamide following a mode of action approach. Toxicol Appl Pharmacol. 2015;289:515-24.

35. Qiu M, Bao W, Wang J, Yang T, He X, Liao Y, et al. FOXA1 promotes tumor cell proliferation through AR involving the notch pathway in endometrial cancer. BMC Cancer. 2014;14:78.

36. Shah AV, Birdsey GM, Peghaire C, Pitulescu ME, Dufton NP, Yang Y, et al. The endothelial transcription factor ERG mediates Angiopoietin-1dependent control of notch signalling and vascular stability. Nat Commun. 2017:8:16002.

37. de La Coste A, Freitas AA. Notch signaling: distinct ligands induce specific signals during lymphocyte development and maturation. Immunol Lett. 2006;102:1-9.

38. Sekine C, Koyanagi A, Koyama N, Hozumi K, Chiba S, Yagita H. Differential regulation of osteoclastogenesis by Notch2/Delta-like 1 and Notch1/ Jagged1 axes. Arthritis Res Ther. 2012;14:R45.

39. Zhang S, Chung WC, Miele L, Xu K. Targeting Met and Notch in the Lfngdeficient, Met-amplified triple-negative breast cancer. Cancer Biol Ther 2014:15:633-42

40. del Álamo D, Rouault H, Schweisguth F. Mechanism and significance of cisinhibition in Notch signalling. Curr Biol. 2011:21:R40-7.

41. Garcia TX, Farmaha JK, Kow S, Hofmann MC. RBPJ in mouse Sertoli cells is required for proper regulation of the testis stem cell niche. Development. 2014;141:4468-78.

42. Garcia TX, Parekh $P$, Gandhi $P$, Sinha K, Hofmann MC. The NOTCH ligand JAG1 regulates GDNF expression in Sertoli cells. Stem Cells Dev. 2017;26: 585-98

43. Rimm DL. What brown cannot do for you. Nat Biotechnol. 2006;24:914-6.

44. Thomas P. Membrane androgen receptors unrelated to nuclear steroid receptors. Endocrinology. 2019;160:772-81.

45. Parekh PA, Garcia TX, Waheeb R, Jain V, Gandhi P, Meistrich ML, et al. Undifferentiated spermatogonia regulate Cyp26b1 expression through NOTCH signaling and drive germ cell differentiation. FASEB J. 2019;33:8423-35.

46. Holdcraft RW, Braun RE. Androgen receptor function is required in Sertoli cells for the terminal differentiation of haploid spermatids. Development. 2004;131:459-67.

47. Nicholls PK, Harrison CA, Walton KL, McLachlan RI, O'Donnell L, Stanton PG. Hormonal regulation of sertoli cell micro-RNAs at spermiation. Endocrinology. 2011;152:1670-83.

48. Hasegawa K, Okamura Y, Saga Y. Notch signaling in Sertoli cells regulates cyclical gene expression of Hes1 but is dispensable for mouse spermatogenesis. Mol Cell Biol. 2012:32:206-15.
49. Tang $X$, Wu S, Shen L, Wei Y, Cao X, Wang Y, et al. Di-(2-ethylhexyl) phthalate (DEHP)-induced testicular toxicity through Nrf2-mediated Notch1 signaling pathway in Sprague-Dawley rats. Environ Toxicol. 2018;33:720-8.

50. Alam MS, Ohsako S, Matsuwaki T, Zhu XB, Tsunekawa N, Kanai Y, et al. Induction of spermatogenic cell apoptosis in prepubertal rat testes irrespective of testicular steroidogenesis: a possible estrogenic effect of di(nbutyl) phthalate. Reproduction. 2010;139:427-37.

51. Hsieh TH, Tsai CF, Hsu CY, Kuo PL, Lee JN, Chai CY, et al. Phthalates induce proliferation and invasiveness of estrogen receptor-negative breast cancer through the AhR/HDAC6/c-Myc signaling pathway. FASEB J. 2012;26:778-87.

52. Wójtowicz AK, Szychowski KA, Wnuk A, Kajta M. Dibutyl phthalate (DBP)induced apoptosis and neurotoxicity are mediated via the aryl hydrocarbon receptor (AhR) but not by estrogen receptor alpha (ERa), estrogen receptor Beta (ERß), or peroxisome proliferator-activated receptor gamma (PPARY) in mouse cortical neurons. Neurotox Res. 2017:31:77-89.

53. Carvalho FL, Marchionni L, Gupta A, Kummangal BA, Schaeffer EM, Ross AE, et al. HES6 promotes prostate cancer aggressiveness independently of Notch signalling. J Cell Mol Med. 2015;19:1624-36.

54. Kondo N, Tohnai G, Sahashi K, lida M, Kataoka M, Nakatsuji H, et al. DNA methylation inhibitor attenuates polyglutamine-induced neurodegeneration by regulating Hes5. EMBO Mol Med. 2019;11:e8547.

55. Kamińska A, Pardyak L, Marek S, Wróbel K, Kotula-Balak M, Bilińska B, et al. Notch signaling regulates nuclear androgen receptor $A R$ and membrane androgen receptor ZIP9 in mouse Sertoli cells. Andrology. 2020;8:457-72.

\section{Publisher's Note}

Springer Nature remains neutral with regard to jurisdictional claims in published maps and institutional affiliations.

Ready to submit your research? Choose BMC and benefit from:

- fast, convenient online submission

- thorough peer review by experienced researchers in your field

- rapid publication on acceptance

- support for research data, including large and complex data types

- gold Open Access which fosters wider collaboration and increased citations

- maximum visibility for your research: over $100 \mathrm{M}$ website views per year

At $\mathrm{BMC}$, research is always in progress.

Learn more biomedcentral.com/submission 